\title{
Pituitary and Leydig cell function in boars actively immunized against gonadotrophin-releasing hormone*
}

\author{
C. A. Awoniyi, V. Chandrashekar, R.D. Arthur $\dagger$, B. D. Schanbacher $\ddagger$, \\ A. G. Amador and R. E. Falvo \\ Department of Physiology, School of Medicine, $\dagger$ Department of Animal Science, Food and \\ Nutrition, School of Agriculture, Southern Illinois University, Carbondale, IL 62901, U.S.A.; and \\ $\ddagger$ U.S. Department of Agriculture, Clay Center, NE 68933, U.S.A.
}

\begin{abstract}
Summary. Crossbred boars were (a) immunized against GnRH conjugated to human serum globulin $(200 \mu \mathrm{g}$ GnRH-hSG) in Freund's adjuvant at 12 weeks of age and boosted at weeks 18 and $20(\mathrm{~N}=10)$, (b) served as controls and received hSG only in adjuvant $(\mathrm{N}=10)$, or castrated at weaning $(\mathrm{N}=10)$. At 24 weeks of age (immediately before slaughter), the boars were challenged with saline or pig $\mathrm{LH}(1 \mu \mathrm{g} / 10 \mathrm{~kg}$ body weight). After slaughter, fresh testicular fragments were incubated with pig LH $(0.05$ and $0.2 \mathrm{ng} / 2 \mathrm{ml}$ medium) to assess the effects of immunization on Leydig cell function. Pituitary contents of $\mathrm{LH}$ and $\mathrm{FSH}$, and testicular $\mathrm{LH}$ receptor content were also measured. The results indicated that plasma $\mathrm{LH}$ and testosterone concentrations, pituitary LH content, testicular LH receptor content, testis and sex accessory organ weights were significantly reduced in GnRH-immunized boars compared to hSGadjuvant controls. However, plasma and pituitary FSH content were not affected by high antibody titres generated against GnRH. The testicular testosterone response to exogenous LH in vivo and in vitro was significantly reduced $(P<0.05)$ in GnRHimmunized boars. These results indicate that active immunization against GnRH impairs pituitary and Leydig cell functions in boars.
\end{abstract}

Keywords: GnRH immunization; testosterone; LH; FSH; LH receptor; boars

\section{Introduction}

Gonadotrophin-releasing hormone (GnRH) has been shown to stimulate the release of both luteinizing hormone ( $\mathrm{LH})$ and follicle-stimulating hormone (FSH) from the adenohypophysis in both male and female mammals (Arimura \& Schally, 1974). This observation has led to the widely accepted concept that GnRH is the primary neurohormone that regulates the release of both gonadotrophins. However, there have been a number of instances in which dichotomy in secretion of LH and FSH has been demonstrated, suggesting that there may be different mechanisms for the regulation of LH and FSH synthesis and secretion (Lorenzen et al., 1981; Sherins et al., 1982; Culler \& Negro-Vilar, 1986, 1987).

In many studies conducted to elucidate the relationship existing between the hypothalamus and pituitary, and to study the physiology of the pituitary gland after deprivation of neurohormones, pituitary stalk transection and hypothalamic lesions have been imposed (Cronin et al., 1982; Norman et al., 1982; Clarke \& Cummins, 1984). However, these methods can induce unintended and disruptive physiological consequences. Active immunization against $\mathrm{GnRH}$ in boars produced

*Reprint requests to: Dr Richard E. Falvo, Department of Physiology, Southern Illinois University, School of Medicine, Carbondale, IL 62901-6512, U.S.A. 
a selective immunological barrier between the hypothalamus and the anterior pituitary (Falvo et al., 1986), and there are morphological changes in the boar testis after active immunization against GnRH (Awoniyi et al., 1987). In the present study, we have examined the effects of active immunization against $\mathrm{GnRH}$ in boars on (i) the role of $\mathrm{GnRH}$ in the regulation of gonadotrophin secretion, (ii) the secondary effect of testicular steroidogenesis by stimulation of Leydig cells in vivo with pig $\mathrm{LH}$ and testicular testosterone production in vitro in response to exposure to pig $\mathrm{LH}$, and (iii) the changes in the testicular LH receptor content.

\section{Materials and Methods}

Animals. Cross-bred boars (Duroc $\times$ Yorkshire $\times$ Hampshire) were randomly assigned to three groups (10 boars/ group), and treated as follows: Group l boars were immunized with $200 \mu \mathrm{g}$ GnRH-human serum globulin (GnRHhSG) conjugate in complete Freund's adjuvant (CFA) at 12 weeks of age and were given booster injections using incomplete Freund's adjuvant in Weeks 18 and 20. Group 2 boars (adjuvant controls) received hSG only in adjuvant, and Group 3 boars were castrated at weaning ( $4-6$ weeks of age). Purified GnRH was made immunogenic by conjugation to the carrier protein, hSG (Cohn fraction IV-1; Sigma Chemical Co., St Louis, MO, U.S.A.), by carbodiimide reaction. Briefly, $200 \mu \mathrm{g} \mathrm{GnRH-hSG}$ conjugate or hSG were dissolved in $1 \mathrm{ml}$ sterile saline $(900 \mathrm{mg} \mathrm{NaCl}$ in $100 \mathrm{ml}$ distilled water; Abbott Laboratories, North Chicago, IL, U.S.A.) and $1 \mathrm{ml}$ of Freund's adjuvant (Sigma Chemical Co.) and emulsified. The antigen was then injected subcutaneously (2 sites) at the basal side of the left and right axillary regions. Blood samples were taken from all boars in Weeks 8, 12, 16, 18, 20, 22 and 24 via anterior vena cava puncture without anaesthesia, and plasma was assayed for testosterone, LH and FSH by radioimmunoassays. At slaughter, the testes, sex accessory organs and pituitary glands were removed and weighed.

Antibody titre to $\mathrm{GnRH}$. Antibody titres generated against GnRH in boars immunized with GnRH-hSG conjugate were determined from plasma samples collected in Weeks 16, 18, 20, 22 and 24 as previously described by Schanbacher (1982), using freshly radioiodinated GnRH.

Pituitary LH and FSH content. Boars in Groups 1 and 2 were exsanguinated and decapitated, and pituitaries were removed, weighed and stored frozen in $4 \mathrm{ml}$ PBS at $-20^{\circ} \mathrm{C}$. Before assay, the pituitary was thawed to $4{ }^{\circ} \mathrm{C}$, homogenized and centrifuged for $30 \mathrm{~min}$ at $1200 \mathrm{~g}$. The supernatant was decanted and assayed for LH and FSH.

Hormone assay. Plasma and pituitary concentrations of LH (Niswender et al., 1970) and testosterone (Falvo \& Nalbandov, 1974) were determined in duplicate samples. Sensitivities for the respective assays were $10 \mathrm{pg} / \mathrm{tube}$ for $\mathrm{LH}$ (LER-778-4, which has an LH biological activity of $0.50 \times \mathrm{NIH}-\mathrm{LH}-\mathrm{S} 1 \mathrm{U} / \mathrm{mg}$ ) and $5 \mathrm{pg} /$ tube for testosterone. The interassay coefficients of variation for $\mathrm{LH}$ and testosterone were $<10 \%$.

Plasma and pituitary concentrations of FSH were quantified by a heterologous double antibody radioimmunoassay procedure. Purified pig FSH (USDA-FSH-PP1) was radioiodinated by the chloramine T method of Greenwood et al. (1963), and was used as the tracer. Pig FSH (pFSH-B-1) was utilized as a reference preparation, and antibodies developed against rat FSH (AFP-C0972881) were used. Although an homologous double-antibody radioimmunoassay using anti-pig FSH (USDA-10-1010) (Guthrie \& Bolt, 1983) produced a linear standard curve, this antiserum was not sensitive enough to allow measurement of FSH in plasma from control or castrated boars at sample volumes of $500 \mu \mathrm{l}$, and so an anti-rat FSH was used. Various amounts of a plasma pool (from castrated boars) produced an inhibition curve which was parallel with the inhibition curve obtained with the pig FSH reference preparation. The slopes of the curve were -3.01 and -3.08 , respectively, which were not statistically different. This antiserum (anti-rat FSH) was used at a final dilution of 1:50 000. The bound radioactive antigen-antibody complex was precipitated by addition of goat anti-rabbit gamma globulin. The sensitivity of the assay was $5 \mathrm{pg} / \mathrm{tube}$. The interassay coefficient of variation was $8 \cdot 7 \%$.

In-vivo testosterone release. At 24 weeks of age (immediately before slaughter), an in-vivo intravenous challenge to saline $(0.5 \mathrm{ml})$ or USDA pig LH-B-1 (AFP-5400) $(1 \mu \mathrm{g} / 10 \mathrm{~kg}$ body weight) dissolved in $0.5 \mathrm{ml}$ sterile saline was conducted.

In-vitro testosterone production. The ability of the testes of animals treated with hSG or GnRH-hSG to produce testosterone in vitro in response to gonadotrophin (pig $\mathbf{L H}$ ) stimulation was tested using procedures previously described (Dufau et al., 197I). Each testis was decapsulated, and fragments (about $200 \mathrm{mg}, 3$ fragments/boar) were obtained and placed in a beaker containing $2 \mathrm{ml}$ PBS for a preincubation wash for $15 \mathrm{~min}$. This preincubation wash was necessary to reduce the large quantities of preformed testosterone released into the medium which would tend to mask testosterone production when stimulated with $\mathbf{L H}$. The fragments were then removed from the preincubation medium and placed in a $25 \mathrm{ml}$ beaker containing $1.9 \mathrm{ml} \mathrm{Krebs}-\mathrm{Ringer}$ bicarbonate buffer previously gassed with $\mathrm{O}_{2}$ : $\mathrm{CO}_{2},(95: 5 \mathrm{v} / \mathrm{v})$ and containing glucose ( $\left.1 \mathrm{mg} / \mathrm{ml}\right)$. Pig LH (USDA-pLH-B-1) was diluted with saline $(0 \cdot 05 \mathrm{ng}$, or $0.2 \mathrm{ng} / 0.1 \mathrm{ml})$ and added to the incubations in $0.1 \mathrm{ml}$ volume. Saline $(0.1 \mathrm{ml})$ was added to the incubations without pig LH. The incubations were carried out for $4 \mathrm{~h}$ at $32^{\circ} \mathrm{C}$ in a Dubnoff metabolic incubator. At the end of the incubation, 
samples of the medium were removed for the measurement of testosterone by radioimmunoassay without purification, since these procedures are not required for valid determination of testosterone concentrations in incubation media (Van Damme et al., 1973).

$L H$ receptor assay. Testicular $\mathbf{L H}$ receptors were measured by radioreceptor assay using a procedure previously characterized for other species (Klemcke \& Bartke, 1981; Klemcke et al., 1981; Amador et al., 1983). The content of protein in testicular membrane preparations used for measurement of LH receptors was determined by a modification of Lowry's procedure (Markwell et al., 1978). Briefly each assay tube contained a membrane preparation concentration equivalent to that obtainable from $10 \mathrm{mg}$ testes and $2 \cdot 18 \mathrm{ng}{ }^{125} \mathrm{I}$-labelled hCG (CR-121, NICHHD). This was found to be a saturating concentration of hCG for the receptors present in the membrane preparation obtained from $10 \mathrm{mg}$ testis. The chloramine-T method was used to radioiodinate the hCG, and the resulting trace had an average specific activity of $30.9 \mu \mathrm{Ci} / \mu \mathrm{g}$ and a maximum binding ability of $42.0 \%$. The $K_{\mathrm{d}}$ for $\mathrm{LH}$ receptors (as determined by Scatchard plot) in pig testes was found to be $1.99 \times 10^{-12}$ (Fig. 1).

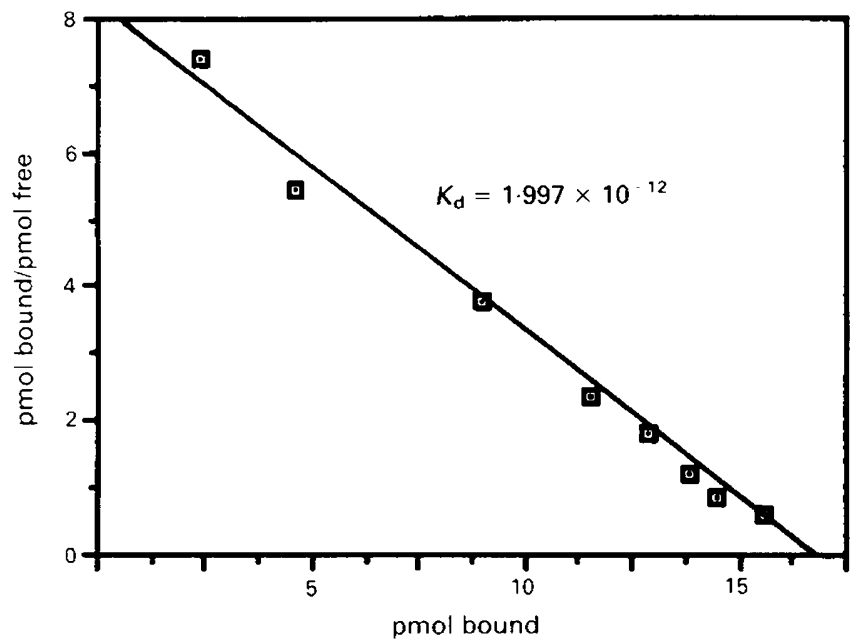

Fig. 1. Scatchard plot of $\mathrm{LH}$ receptors in boar testicular membrane preparation using ${ }^{125} \mathrm{I}$ labelled hCG.

Statistical analysis. Data were analysed by least-squares analysis of variance and corresponding F-test (Dixon \& Massey, 1969). Post-hoc comparisons of means were done by Tukey (Kirk, 1968) and Scheffe tests (Scheffe, 1959).

\section{Results}

Antibody titre

The immunization schedule effectively induced antibody production capable of binding GnRH. Antibody titres in GnRH-immunized boars were detectable 4 weeks after primary immunization $(18 \cdot 3 \pm 2 \cdot 3 \%$ at $1: 1000$ plasma dilution). The titre rose markedly in response to both the first and second boosters $(77 \cdot 6 \pm 3 \cdot 2 \% ; 83 \pm 2 \cdot 6 \%$, at $1: 1000$ plasma dilution), and remained elevated during the remainder of the experiment $(87 \cdot 2 \pm 3 \cdot 4 \%)$.

\section{Testes and accessory sex organs}

Before slaughter, there was a correlation between the GnRH antibody titre, and the degree of testicular atrophy in GnRH-immunized boars. Testes of these boars were small, flaccid and retracted into the inguinal canal. The paired testes and accessory sex organ (Cowper's gland, prostate, and seminal vesicle) weights for the different groups are shown in Fig. 2. The weights of the testes in GnRH-immunized boars were significantly reduced. Similarly accessory sex organ 
weights in GnRH-immunized boars and castrated controls were significantly different from each other $(P<0.05)$ and were significantly reduced when compared with those of adjuvant-injected controls.
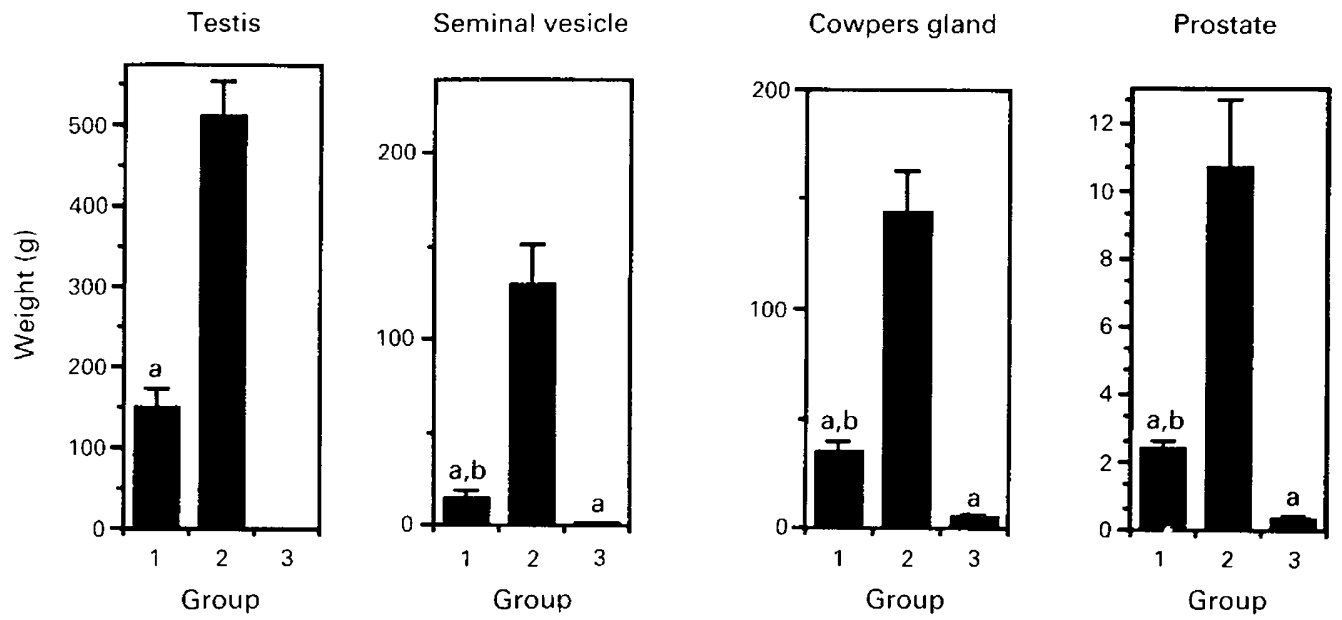

Fig. 2. Paired testis and sex accessory gland weights in GnRH-immunized (Group 1), adjuvant control (Group 2), and castrated (Group 3) boars. Values are mean \pm s.e.m. for 10 boars/ group. ${ }^{a} P<0.05$ compared with Group 2; ${ }^{b} P<0.05$ compared with Group 3.

\section{Testosterone, LH and FSH concentrations}

The high antibody titre observed in response to the first booster at Week $18(77.6 \% ; 1: 1000$ plasma dilution) coincided with low plasma concentrations of both testosterone and $\mathrm{LH}$ in GnRHimmunized boars (Fig. 3), and showed a significant decrease compared to adjuvant-injected control boars. In GnRH-immunized boars, plasma concentrations of GnRH antibody, which were consistently $>70 \%$ binding after the first booster, impeded the synthesis of pituitary LH and caused a significant reduction in pituitary $\mathrm{LH}$ content as compared to adjuvant-treated controls $(0.14 \pm 0.01$ vs $0.25 \pm 0.02 \mathrm{ng} / \mathrm{mg}$ pituitary; $P<0.05)$.

In contrast to the low to non-detectable concentrations of testosterone and LH seen in response to high antibody titres to GnRH, FSH values in GnRH-immunized boars were unaffected and did not differ when compared with those of adjuvant-treated control boars throughout the experimental period. Concentrations of FSH in castrated boars were significantly elevated throughout the experiment and differed significantly from those in the GnRH-immunized and adjuvant control groups. There was no significant difference in pituitary FSH content in GnRH-immunized boars compared to the adjuvant-treated controls $(3 \cdot 1 \pm 0.5$ vs $5.1 \pm 1.0 \mathrm{ng} / \mathrm{mg}$ pituitary).

\section{Treatment with $L H$ in vivo and in vitro}

Intravenous injection of saline resulted in no significant alteration in plasma testosterone concentrations (Fig. 4). However, administration of LH significantly increased plasma testosterone concentrations at $60 \mathrm{~min}$ in both groups.

Pig LH at 0.05 or $0.2 \mathrm{ng} / 2 \mathrm{ml}$ medium did not stimulate testosterone production by the testicular fragments of boars immunized against GnRH $(0.04 \pm 0.01$ vs $0.32 \pm 0.04 \mathrm{ng} / \mathrm{mg} ; P<0.05$ at a dose of $0.05 \mathrm{ng} \mathrm{LH} / 2 \mathrm{ml}$ medium and $0.04 \pm 0.01$ vs $0.55 \pm 0.05 \mathrm{ng} / \mathrm{mg}, P<0.05$ at a dose of $0.2 \mathrm{ng} \mathrm{LH} / 2 \mathrm{ml}$ medium). However, $0.2 \mathrm{ng} \mathrm{LH}$ significantly increased testosterone production in tissue from adjuvant-treated controls (saline $=0.27 \pm 0.04, \mathrm{LH}=0.55 \pm 0.05 \mathrm{ng} / \mathrm{mg} ; P<0.05$ ). 


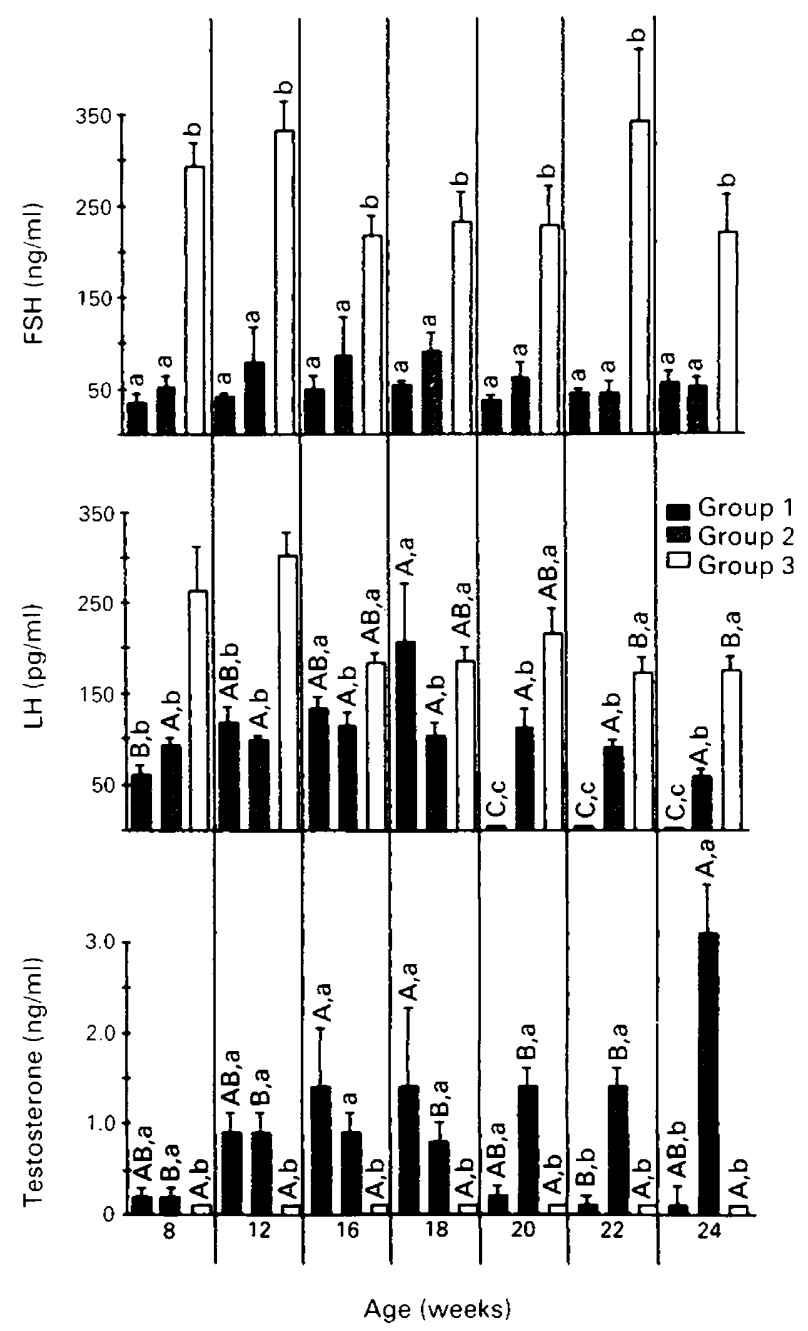

Fig. 3. Plasma concentrations of testosterone, LH and FSH in GnRH-immunized (Group 1), adjuvant control (Group 2), and castrated (Group 3) boars. Values are mean \pm s.e.m. for 10 boars/group. Uppercase superscripts denote differences $(P<0.05)$ within each group over weeks; lower case superscripts indicate differences $(P<0.05)$ between groups. Preimmunization levels of hormones are shown at 8 and 12 weeks of age.

\section{LH receptor}

Active immunization against $\mathrm{GnRH}$ did not significantly decrease the concentration of testicular $\mathrm{LH}$ receptors, but reduced the total content of the $\mathrm{LH}$ receptor compared to adjuvant-treated control boars $(58.5 \pm 18 \cdot 0$ vs $327 \cdot 1 \pm 44 \cdot 1 \mathrm{pmol} /$ pair of testes, $P<0 \cdot 001)$.

\section{Discussion}

This study demonstrates that young boars are capable of generating high levels of GnRH antibodies after active immunization against GnRH. Binding of ${ }^{125}$ I-labelled GnRH with sera of 


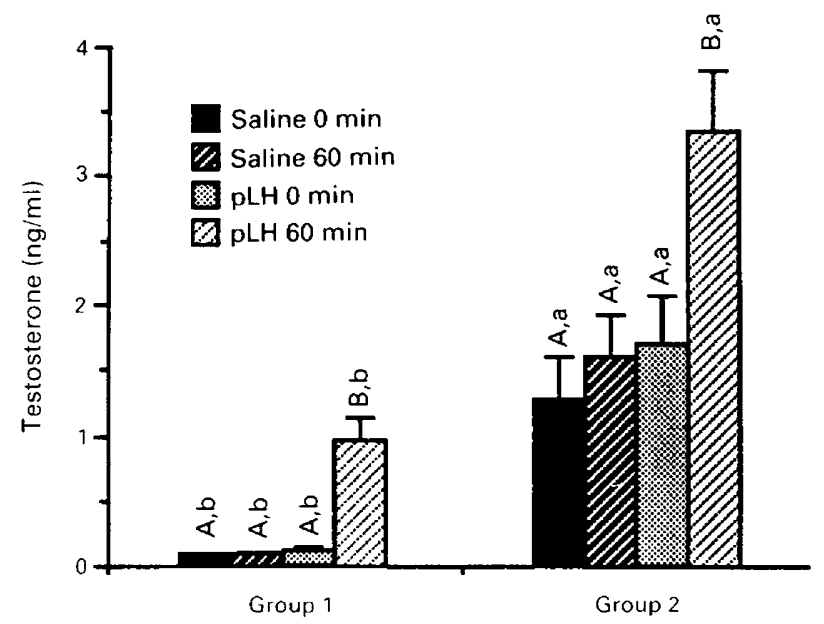

Fig. 4. Plasma testosterone concentrations in GnRH-immunized (Group 1) and adjuvant control (Group 2) boars after an in-vivo saline and pig LH challenge. Values are mean \pm s.e.m. for 10 boars/group. Uppercase superscripts denote differences $(P<0.05)$ within each group over time; lower case superscripts indicate differences $(P<0.05)$ between groups.

immunized boars (at a dilution of 1:1000) suggests that GnRH antibodies effectively neutralized endogenous GnRH.

When GnRH antibody titres reached high levels, plasma LH concentrations became undetectable, as a result of insufficient free GnRH binding to pituitary gonadotrophes. Low to nondetectable concentrations of plasma testosterone resulted, with a reduction in both the size and weight of testes and sex accessory organs. Similar findings for the effect of GnRH immunization have been reported for males of other species such as rats (Sharpe \& Fraser, 1978, 1979; Shiota et al., 1981), rabbits (Arimura et al., 1973), monkeys (Chappel et al. 1980), and ram lambs (Schanbacher, 1982). Accessory sex organ weights were reduced in castrated compared to GnRHimmunized animals, most probably due to the increased period of androgen deprivation.

In this study, FSH concentrations were not affected in spite of the high antibody titres to GnRH, which leads us to suggest that there may be a component for FSH secretion independent of GnRH in boars. In addition, this divergent effect of GnRH immunization on LH and FSH secretion supports the hypothesis of a separate releasing hormone for FSH. Nevertheless, the possibility of reduced FSH concentrations in these boars after chronic GnRH immunization cannot be ruled out.

The differential regulation of $\mathrm{LH}$ and FSH in other species has been demonstrated (Thompson et al., 1979; Sherins et al., 1982; Culler \& Negro-Vilar, 1986, 1987). Since inhibin secreted by the testis has a role in FSH secretion, it is possible that inhibin was not affected in GnRH-immunized boars, contributing to the unaltered plasma FSH values in this study. However, providing proof of the factor(s) that control the synthesis and secretion of FSH (other than GnRH) in boars requires further investigation.

Changes in testicular responsiveness to LH are usually monitored by quantifying testosterone production after gonadotrophin stimulation in vivo (Lincoln et al., 1982) and in vitro (Wolfe et al., 1981). However, in-vitro testosterone production by incubating pig testicular tissue with LH has yet to be reported. In this study, testosterone production was demonstrated only in vivo but not in vitro after treatment of immunized boars with pig LH. The severe damage of Leydig cells in boars after active immunization against GnRH (Awoniyi et al., 1987) may explain the inability of the testes to produce testosterone in vitro. On the other hand, the ability of the testes to produce testosterone in vivo suggests that there may be another factor(s) acting synergistically with pig LH 
when injected to augment testosterone release. Other factors implicated to produce testosterone include intratesticular factors (Sharpe, 1984), and a thymus factor (Pedernera et al., 1986). FSH promotes the development and increased sensitivity of LH receptors (MacKinnon et al., 1978), therefore the presence of normal FSH concentrations in the immunized boars also may have increased the sensitivity of $\mathrm{LH}$ receptors to $\mathrm{LH}$. Since the testosterone concentrations after administration of pig LH in GnRH-immunized boars were still below the baseline values observed in adjuvant-treated controls, it may be concluded that the testes of these boars have less steroidogenic capacity.

Morphometric analysis showed a drastic reduction in the volume percentage of Leydig cells in the testes of GnRH-immunized boars (Awoniyi et al., 1987). This observation may explain the decrease in the total content of the $\mathrm{LH}$ receptor in spite of a normal concentration of the receptor, since similar changes have been observed in Syrian and Siberian hamsters treated with anti-GnRH serum (Bartke et al., 1987).

Uniformity and a high percentage of response to immunization must be demonstrated before using this method as a practical alternative to surgical castration. However, this type of uniform response has not been seen in previous studies in rats (Fraser et al., 1974), monkeys (Chappel et al., 1980), rabbits (Arimura et al., 1973) and dogs (Schanbacher et al., 1983) immunized against GnRH. Combined with the high success rate of immunocastration in boars observed in our previous study (Falvo et al., 1986), our present findings provide an added incentive to use this approach both experimentally and practically as an alternative to surgical castration.

We thank the USDA, National Hormone and Pituitary Program, NIH and Dr A. F. Parlow for gifts of pig gonadotrophins and other RIA reagents used in this study, and Dr G. D. Niswender for the pig LH antibody. The work was supported in part by the Illinois Pork Producers Association.

\section{References}

Amador, A., Steger, R.W., Bartke, A., Johns, A., Hayashi, R.H. \& Stallings, A. (1983) Pituitary and testicular function in spontaneously hypertensive rats. J. Androl. 4, 67-70.

Arimura, A. \& Schally, A.V. (1974) Hypothalamic LHand FSH-releasing hormone: reevaluation of the concept that one hypothalamic hormone controls the release of LH and FSH. In Biological Rhythms in Neuroendocrine Activity, pp. 73-90. Ed. M. Kawakami. Igaku Shoin Ltd, Tokyo.

Arimura, A., Sato, H., Kamasaka, T., Worobec, R.B., Debeljuk, L., Dunn, J. \& Schally, A.V. (1973) Production of antiserum to LH-releasing hormone ( $\mathrm{LH}$ $\mathrm{RH}$ ) associated with gonadal atrophy in rabbits: development of radioimmunoassay for LH-RH. Endocrinology 93, 1092-1103.

Awoniyi, C., Chandrashekar, V., Falvo, R.E., Arthur, R., Schanbacher, B.D. \& Amador, A. (1987) Leydig cell functions in boars actively immunized against LHRH. Biol. Reprod. 36 (Suppl. 1), Abstr. 49.

Bartke, A., Schanbacher, B.D., Amador, A.G., Klemcke, H.G. \& Chandrashekar, V. (1987) Effects of immunoneutralization of luteinizing hormone-releasing hormone on testicular prolactin and luteinizing hormone (LH) receptors in the golden hamster and on $\mathbf{L H}$ receptor in the Djungarian hamster. Endocrinology 121, 2027-2034.

Chappel, S.C., Ellington, W.E., Huckins, C., Herbert, D.C. \& Spies, H.G. (1980) Active immunization of male rhesus monkeys against luteinizing hormone releasing hormone. Biol. Reprod. 22, 333-342.
Clarke, I.J. \& Cummins, J.T. (1984) Direct pituitary effects of estrogen and progesterone on gonadotrophin secretion in the ovariectomized ewe. Neuroendocrinology 39, 267-274.

Cronin, M.J., Cheung, C.Y., Weiner, R.I. \& Goldsmith, P.C. (1982) Mammotroph and gonadotroph volume percentage in the rat anterior pituitary after lesion of the basal hypothalamus. Neuroendocrinology 34, 140-147.

Culler, M.D. \& Negro-Vilar, A. (1986) Evidence that pulsatile follicle stimulating hormone secretion is independent of endogenous luteinizing hormonereleasing hormone. Endocrinology 118, 609-612.

Culler, M.D. \& Negro-Vilar, A. (1987) Pulsatile follicle stimulating hormone secretion is independent of luteinizing hormone-releasing hormone (LHRH): pulsatile replacement of LHRH bioactivity in LHRH immunoneutralized rats. Endocrinology 120, 2011-2021.

Dixon, W.J. \& Massey, F.J. (1969) Introduction to Statistical Analysis. McGraw-Hill Book Co., Inc., New York.

Dufau, M.L., Catt, K.J. \& Tsuruhara, T. (1971) Gonadotrophin stimulation of testosterone production by the rat testis in vitro. Biochim. Biophys. Acta 272, 574-579.

Falvo, R.E. \& Nalbandov, A.V. (1974) Radioimmunoassay of peripheral plasma testosterone in males from eight species using a specific antibody without chromatography. Endocrinology 95, 1466-1468.

Falvo, R.E., Chandrashekar, V., Arthur, R.D., Kuenstler, A.R., Hasson, T., Awoniyi, C. \& Schanbacher, B.D. 
(1986) Effects of active immunization against LHRH or $\mathrm{LH}$ in boars: reproductive consequences and performance traits. J. Anim. Sci. 63, 986-994.

Fraser, H.M., Gunn, A., Jeffcoate, S.L. \& Holland, D.T. (1974) Effect of active immunization to luteinizing hormone releasing hormone on serum and pituitary gonadotropins, testes and accessory sex organs in the male rat. J. Endocr. 63, 399-406.

Greenwood, F.C., Hunter, W.M. \& Glover, J.S. (1963) The preparation of ${ }^{125}$ I-labelled human growth hormone of high specific radioactivity. Biochem. $J$. 89, $114-124$.

Guthrie, H.D. \& Bolt, D.J. (1983) Changes in plasma oestrogen, luteinizing hormone, follicle stimulating hormone and 13,14-dihydro-15-ketone-prostaglandin $\mathrm{F}_{2} \alpha$ during blockage of luteolysis in pigs after human chorionic gonadotropin treatment. J. Anim. Sci. 57, 993-1000.

Kirk, R.E. (1968) Experimental Design: Procedures for the Behavioral Sciences. Brooks/Cole Publishing Company, Belmont, California.

Klemcke, H.G. \& Bartke, A. (1981) Effects of chronic hyperprolactinemia in mice on plasma gonadotropin concentrations and testicular human chorionic gonadotropin binding sites. Endocrinology 108, 1763-1768.

Klemcke, H.G., Bartke, A. \& Goldman, B.D. (1981) Plasma prolactin concentrations and testicular human chorionic gonadotropin binding sites during short photoperiod-induced testicular regression and recrudescence in the golden hamster. Biol. Reprod. 25, 536-548.

Lincoln, G.A., Fraser, H.M. \& Fletcher, T.J. (1982) Antler growth in male red deer (Cervus elephus) after active immunization against LH-RH. J. Reprod. Fert. 66, 703-708.

Lorenzen, J.R., Dworkin, G.H. \& Schwartz, N.B. (198I) Specific FSH suppression in male rat by porcine follicular fluid. Am. J. Physiol. 240, E209-219.

MacKinnon, P.C.B., Puig-Duran, E. \& Laynes, R. (1978) Reflections on the attainment of puberty in the rat: have circadian signals a role to play in its onset? $J$. Reprod. Fert. 52, 401-412.

Markwell, M.A.K., Haas, M.S., Bieber, L.L. \& Tolbert, N.E. (1978) A modification of the Lowry procedure to simplify protein determination in membrane and lipoprotein samples. Analyt. Biochem. 87, 206-210.

Niswender, G.D., Reichert, L.E. \& Zimmerman, D.R. (1970) Radioimmunoassay of serum levels of luteinizing hormone throughout the estrous cycle of pigs. Endocrinology 87, 576-580.

Norman, R.L., Gliessman, P., Lindstrom, S.A., Hill, J. \& Spies, H.G. (1982) Reinitiation of ovulatory cycles in pituitary stalk-sectioned rhesus monkeys: evidence for a specific hypothalamic message for the preovulatory release of luteinizing hormone. Endocrinology 111, 1874-1882.

Pedernera, E., Diaz-Osuna, J. \& Calcagno, M. (1986) A thymus factor influences the in vitro testosterone secretion of Leydig cells in rats. Life Sci. 38, 779-787.

Schanbacher, B.D. (1982) Response of ram lambs to active immunization against testosterone and luteinizing hormone releasing hormone. Am. J. Physiol. 242, E201-205.

Schanbacher, B.D., English, H.F., Gross, D., Santen, R.J., Walker, M.F. \& Falvo, R.E. (1983) Animal model of isolated gonadotropin deficiency. I. Hormonal response to LHRH immunoneutralization. $J$. Androl. 4, 233-239.

Scheffe, H. (1959) The Analysis of Variance. John Wiley Co. Inc., New York.

Sharpe, R.M. (1984) Intratesticular factor controlling testicular function. Biol. Reprod. 30, 29-49.

Sharpe, R.M. \& Fraser, H.M. (1978) The influence of sexual maturation and immunization against LH-RH on testicular sensitivity to gonadotrophin stimulation in vitro. Int. J. Androl. 1, 501-508.

Sharpe, R.M. \& Fraser, H.M. (1979) Leydig cell function in rats chronically deprived of normal gonadotropin stimulation: the effect of treatment with hCG. Int. J. Androl. 2, 395- 407.

Sherins, R.J., Patterson, A.P., Brightwell, D., Udelsman, R. \& Sarton, J. (1982) Alteration in the plasma testosterone/estradiol ratio: an alternative to the inhibin hypothesis. Ann. N.Y. Acad. Sci. 383, 295-306.

Shiota, K., Takahashi, M. \& Suzuki, Y. (1981) Testicular function of actively immunized male rats with $\mathrm{LH}$ releasing hormone (LHRH): a possible role of prolactin on regulation of spermatogenesis. Endocrinol. japon. 28, 521-534.

Thompson, D.L., Jr, Pickett, B.W., Squires, E.L. \& Nett, T.M. (1979) Effect of testosterone and estradiol-17 $\beta$ alone and in combination with LH and FSH concentrations in blood serum and pituitary of geldings and in serum after administration of GnRH. Biol. Reprod. 21, 1231-1237.

Van Damme, M.P., Robertson, D.M., Romani, P. \& Diczfalusy, E. (1973) A sensitive in vitro bioassay method for luteinizing hormone (LH) activity. Acta endocr., Copenh. 74, 642-658.

Wolfe, H.G., Bartke, A., Amador, A., Van Sickle, M., Dalterio, S. \& Brown, D. (1981) Testicular function in strains of mice selected for differences in gonadotrophin-induced ovulation rate. J. Endocr. 90, 367-373.

Received 8 February 1988 